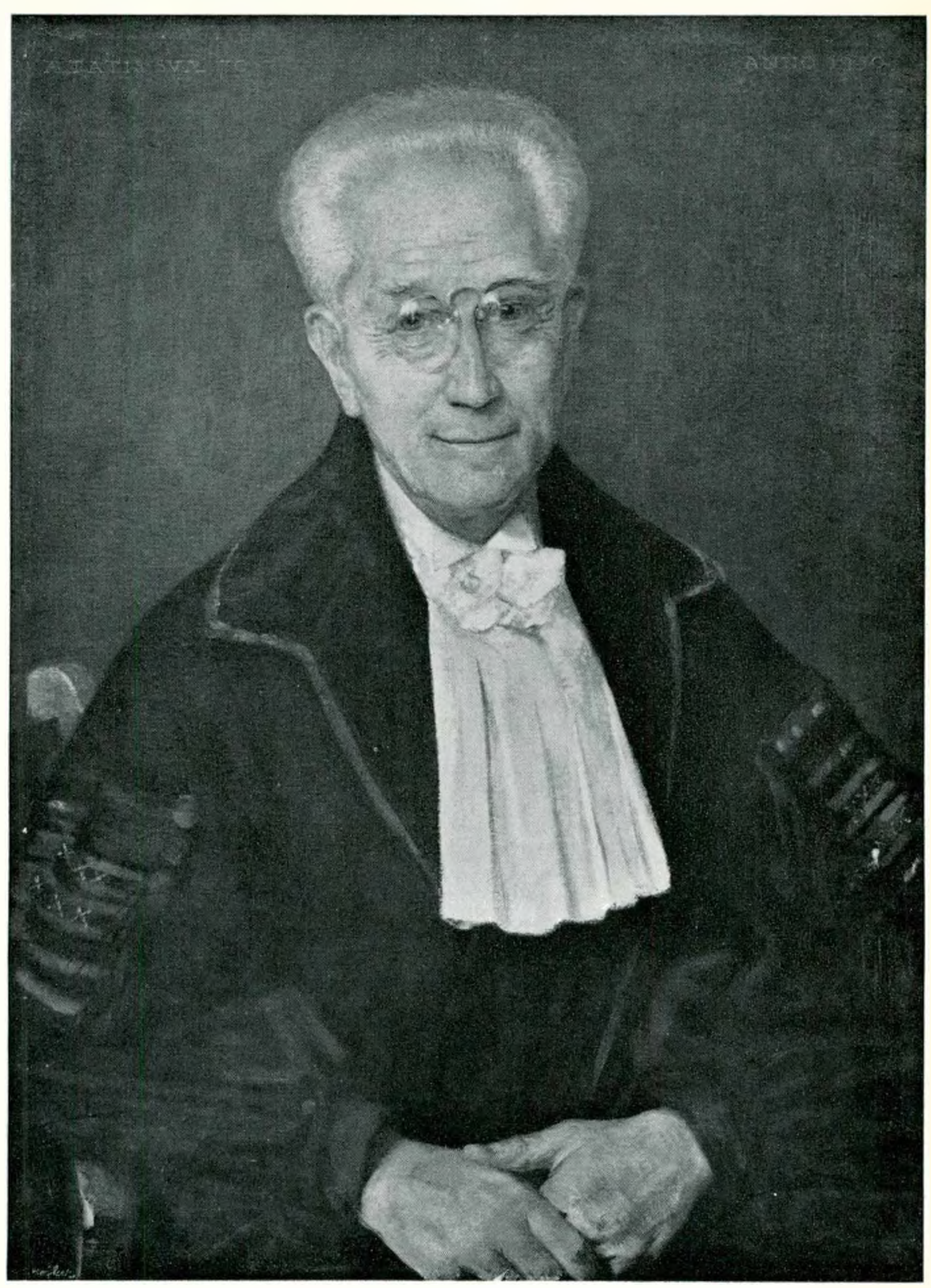





\section{VERANTWOORDING VAN HET LIMPERGNUMMER}

Op 21 december 1959 heeft Prof. Dr. Th. Limperg Jr. de leeftijd van 80 jaar bereikt. De Redactie van het Maandblad voor Accountancy en Bedrijfshuishoudkunde heeft gemeend, dat zij op deze bijzondere dag niet met een eenvoudige gelukwens zou kunnen volstaan. Ter ere van de huidige nestor der accountants en bedrijfseconomen, die zoveel voor de ontwikkeling van beroep en wetenschap heeft betekend, is dit speciale decembernummer tot stand gekomen en Limperg op zijn verjaardag aangeboden.

Alle schrijvers, die zijn uitgenodigd een bijdrage voor dit Limpergnummer te leveren, hebben zich zonder enige aarzeling tot medewerking bereid verklaard; dit moge op zichzelf reeds als een verantwoording van deze bijzondere uitgave worden gezien.

De Redactie hoopt en vertrouwt, dat deze uitgave, zowel door Limperg als door de lezers, met belangstelling en waardering ter hand zal worden genomen. Het streven van de Redactie blijft ook voor de toekomst gericht op hetgeen door Limperg en de overige oprichters van het M.A.B. in 1924 als beleidslijn is aangegeven: het uitgeven van een onafhankelijk vakblad, waarin naast redacteuren en geregelde medewerkers ook schrijvers uit ruimere kring hun medewerking verlenen. Ook dit Limpergnummer getuigt van deze gedachte en daarmede van Limperg's geest. 